\title{
Calcium and protein in bone health*
}

\author{
Bess Dawson-Hughes \\ Calcium and Bone Metabolism Laboratory, The Jean Mayer USDA Human Nutrition Research Center on Aging, \\ Tufts University, 711 Washington St, Boston, MA 02111, USA
}

\begin{abstract}
Dietary protein has several opposing effects on Ca balance and its net effect on bone is not well established. It has long been recognized that increasing protein intake increases urinary $\mathrm{Ca}$ excretion. More recently, it has been observed that increasing dietary protein raises the circulating level of insulin-like growth factor-1, a growth factor that promotes osteoblast formation and bone growth. Other effects of protein on the Ca economy have been suggested in some studies, but they are less well established. Several studies have examined associations between protein intake and bone loss and fracture rates. In the original Framingham cohort subjects with lower total and animal protein intakes had greater rates of bone loss from the femoral neck and spine than subjects consuming more protein. In another study higher total (and animal) protein intakes were associated with a reduced incidence of hip fractures in post-menopausal women. In contrast, a high animal:plant protein intake has been associated with greater bone loss from the femoral neck and a greater risk of hip fracture in older women. Higher total and higher animal protein intakes have also been associated with increased risk of forearm fracture in younger post-menopausal women. In a recent study it was found that increasing dietary protein was associated with a favourable (positive) change in bone mineral density of the femoral neck and total body in subjects taking supplemental calcium citrate malate with vitamin $\mathrm{D}$, but not in those taking placebo. The possibility that $\mathrm{Ca}$ intake may influence the impact of dietary protein on the skeleton warrants further investigation.
\end{abstract}

Calcium balance: Protein intake: Insulin-like growth factor 1: Bone health

Protein and $\mathrm{Ca}$ are major components of bone tissue. The bone tissue contains (w/w) about $70 \%$ mineral, $8 \%$ water and $22 \%$ protein, mainly type I collagen. Collagen consists of three polypeptide chains bound together in a triple helix configuration by cross-linking $\mathrm{H}$ bonds between hydroxyproline, hydroxylysine and other charged residues. This organic matrix material is mineralised with $\mathrm{Ca}$ and $\mathrm{P}$ to form bone. Bone tissue undergoes continuous remodelling and an adequate supply of mineral and amino acid substrate is needed to support the formation phase of bone remodelling. Oxlund et al. (1996) have found decreased concentrations of collagen cross-links in cancellous bone derived from the vertebral bodies of osteoporotic patients compared with age- and gender-matched controls. These investigators have also related reduced collagen cross-links to decreased bone strength in rats.

\section{Dietary calcium and protein: actions and mechanisms}

In addition to their passive roles as substrate for bone formation, dietary $\mathrm{Ca}$ and protein also play active roles in bone metabolism. An inadequate intake of $\mathrm{Ca}$ results in a sequential reduction in the circulating $\mathrm{Ca}^{2+}$ concentration and an increase in parathyroid hormone secretion. Parathyroid hormone increases bone resorption, reduces renal $\mathrm{Ca}$ excretion and indirectly stimulates intestinal $\mathrm{Ca}$ absorption. Small increases in parathyroid hormone over time that result from an inadequate dietary $\mathrm{Ca}$ (or vitamin $\mathrm{D}$ ) intake cause a chronic increase in bone turnover and a steady loss of bone mass, both of which increase risk of fracture.

Dietary protein has several effects on $\mathrm{Ca}$ handling that result in increased urinary $\mathrm{Ca}$ excretion. Dietary protein of both animal and plant origin leads to endogenous acid production. Diet-induced low-grade metabolic acidosis causes hypercalciuria, possibly by decreasing renal tubular re-absorption of Ca (Sutton et al. 1979), by cell-mediated bone resorption (Kraut et al. 1986) and/or by direct physiochemical dissolution of bone (Bushinsky et al. 2001). The mean increases in urinary Ca resulting from increases in protein intake from twelve published studies are shown in Fig. 1. These points fall along a fairly tight regression line.

\footnotetext{
Abbreviations: BMD, bone mineral density; IGF-1, insulin-like growth factor-1.

Corresponding author: Dr Bess Dawson-Hughes, fax +1617 556 3305, email Bess.Dawson-Hughes@Tufts.edu

*This material is based on work supported by a grant (AG10353) from the National Institutes of Health and by the US Department of Agriculture, under agreement no. 58-1950-9001. Any opinions, findings, conclusions or recommendations expressed in this publication are those of the author, and do not necessarily reflect the view of the US Department of Agriculture.
} 


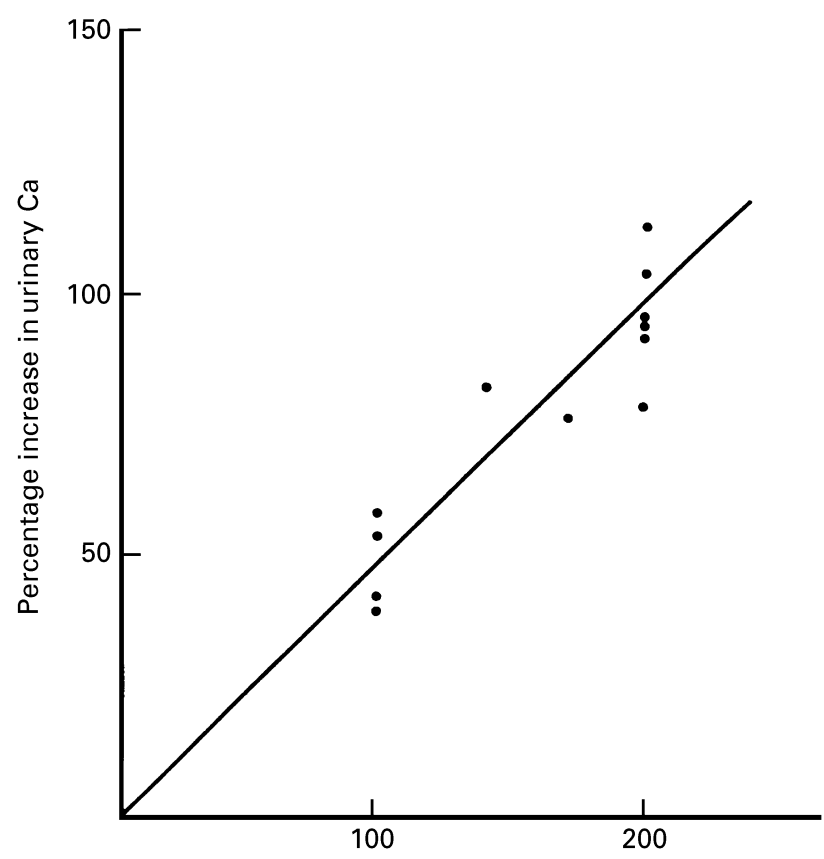

Percentage increase in protein intake

Fig. 1. Mean percentage change in urine calcium $v$. change in protein intake from twelve published studies; $r 0.85$. (From Hegsted \& Linkswiler 1981; reproduced with permission.)

It has been recognised more recently that dietary protein increases circulating levels of insulin-like growth factor (IGF)-1, a growth factor that is thought to play an important role in bone formation. The clearest evidence for this role in man is the $80 \%$ increase in serum IGF-1 levels observed after 6 months of supplementation with $20 \mathrm{~g}$ protein/d in relatively-malnourished elderly patients with recent hip fractures (Schürch et al. 1998; Fig. 2). Serum IGF-1-binding protein levels did not change significantly with protein supplementation in this study. Other supporting evidence comes from two milk intervention studies in healthy subjects with normal usual diets. Milk contains $300 \mathrm{mg} \mathrm{Ca}$ and $9 \mathrm{~g}$ protein $/ 237 \mathrm{ml}$ serving, as well as many other components. Cadogan et al. (1997) reported an increase of about $20 \%$ in serum IGF-1 levels in girls, mean age 12 years, who consumed an extra $474 \mathrm{ml}$ (1 pint) milk per d. In the other study adult men and women who consumed three extra servings of milk per d had $14 \%$ higher serum IGF-1 levels after 12 weeks than did unsupplemented controls (Heaney et al. 1999). Protein restriction extensively decreased type 1 collagen mRNA content in bone tissues in ovariectomised rats (Higashi et al. 1996). In the same study protein restriction decreased the femur contents of the main binding protein, IGF-binding protein-3, but not IGF-binding protein-2 or IGF- binding protein-4.

Dietary protein may alter $\mathrm{Ca}$ absorption, but evidence for this effect in man is limited. Kerstetter et al. (1998) reported that absorption increased in young women fed high-protein diets for $4 \mathrm{~d}$. In contrast, many careful balance studies have not detected an effect of dietary protein on Ca absorption. The latter is illustrated in the $74 \mathrm{~d}$ balance study by Hegsted \& Linkswiler (1981; Fig. 3), in which healthy young women with $\mathrm{Ca}$ intakes of $500 \mathrm{mg} / \mathrm{d}$ were fed $123 \mathrm{~g}$ protein/d for

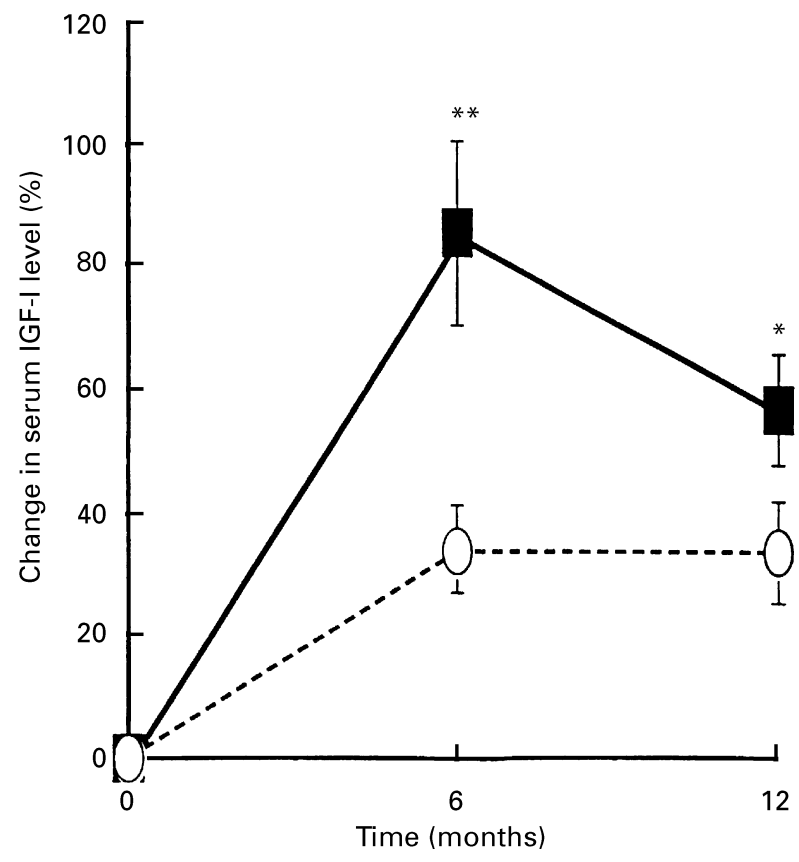

Fig. 2. Change in serum insulin-like growth factor (IGF)-1 levels (ם) of eighty-two relatively-malnourished elderly patients with recent hip fractures after 6 months of supplementation with $20 \mathrm{~g}$ protein/d. Values are means with their standard errors represented by vertical bars. Mean values were significantly different in the supplemented (घ- - ) and control $(\bigcirc---\bigcirc)$ groups: * $P<0.05,{ }^{* *} P<0.01$. Serum IGF-1-binding protein levels were not significantly changed by protein supplementation (From Schürch et al. (1998); reproduced with permission.)

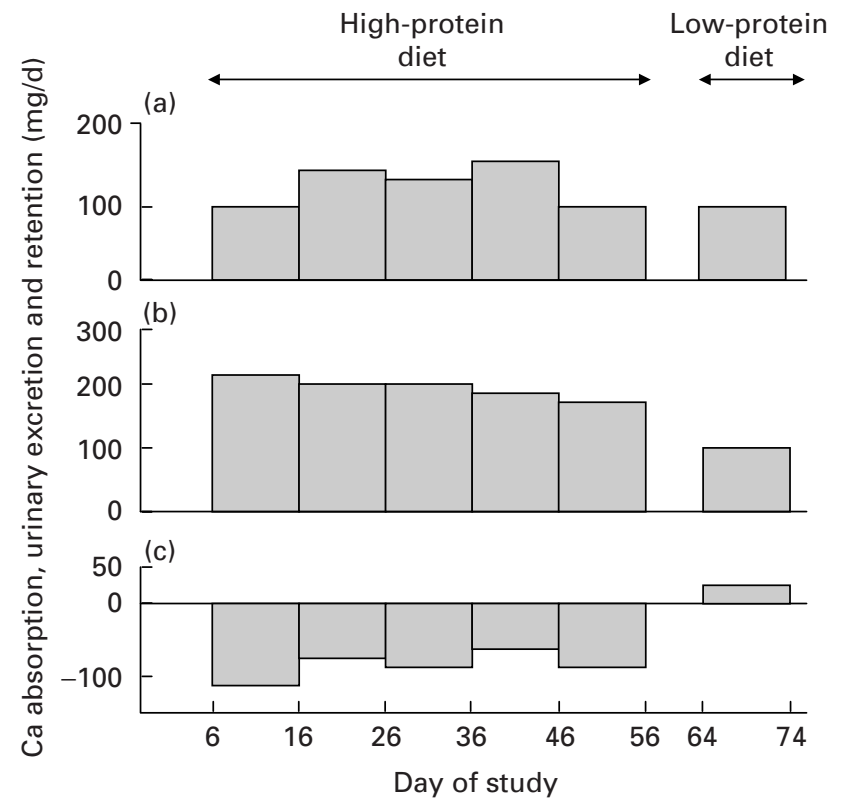

Fig. 3. Calcium absorption (a) urinary excretion (b) and retention (c) of six healthy young women with calcium intakes of $500 \mathrm{mg} / \mathrm{d}$ who were fed $123 \mathrm{~g}$ protein/d for $56 \mathrm{~d}$ and then $46 \mathrm{~g}$ protein/d for $18 \mathrm{~d}$. (From Hegsted \& Linkswiler 1981; reproduced with permission). 
$56 \mathrm{~d}$ and then $46 \mathrm{~g}$ protein/d for $18 \mathrm{~d}$. Changing from high to low protein intake had no effect on $\mathrm{Ca}$ absorption, although it had the other expected effects of lowering urinary $\mathrm{Ca}$ excretion and increasing net $\mathrm{Ca}$ retention. In summary, current evidence reveals that dietary protein potentially has both positive and negative effects on bone metabolism.

\section{Dietary protein, bone mass and fractures: observational studies}

Among observational studies, evidence for associations between protein intake and bone mass or fracture rates was varied, and showed positive, negative and no associations. Dietary protein and total bone mineral density (BMD) for the hip were positively associated in post-menopausal women in the Third National Health and Nutrition Examination Survey (Kerstetter et al. 2000). Hannan et al. (2000) found that a higher protein intake (both total and animal protein) was associated with favourable 4-year changes in BMD of the femoral neck and spine in community-dwelling elderly men and women (Fig. 4). These subjects consumed an average of $68 \mathrm{~g} / \mathrm{d}$ protein and $800 \mathrm{mg} / \mathrm{d} \mathrm{Ca}$. Munger et al. (1999) identified a $69 \%$ reduction in risk of hip fracture with increasing animal protein intake in a large cohort of post-menopausal women. In contrast, in the Nurses' Health Study (Feskanich et al. 1996) no association was found between protein intake and risk of hip fracture, but a $25 \%$ increase in risk of forearm fracture was identified in women consuming $>80 \mathrm{~g}$ protein/d compared with those consuming $<51 \mathrm{~g}$ protein/d. The mean Ca intake was $720 \mathrm{mg} / \mathrm{d}$.

Diets rich in animal protein tend to have a greater overall acid potential, because meat contains more chloride and fewer countering precursors of alkali than plants. Sellmeyer

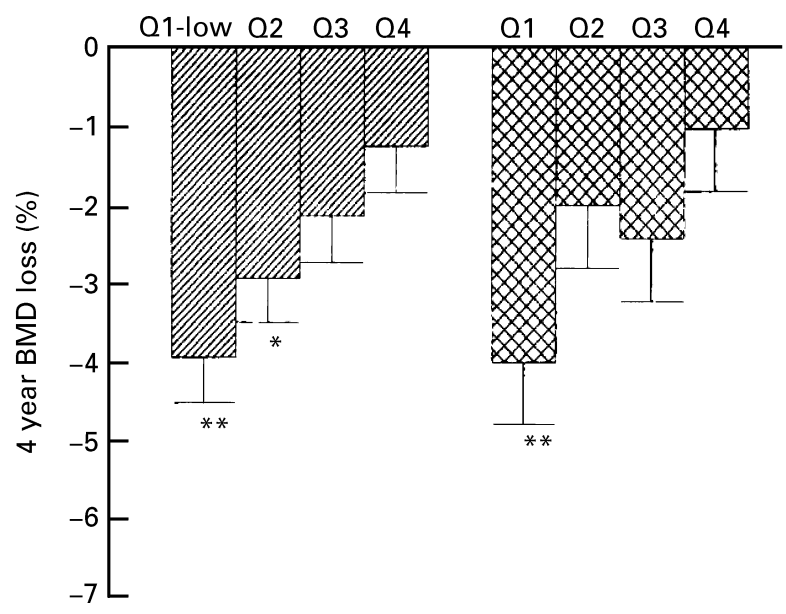

Fig. 4. Protein intake and rates of femoral neck (שn) and lumbar spine (ख) bone loss in 615 community-dwelling elderly men and women participating in the Framingham Osteoporosis Study. These subjects consumed an average of $68 \mathrm{~g}$ protein $/ \mathrm{d}$ and $800 \mathrm{mg}$ calcium/d. Q1-Q4, quartiles of protein intake. Values are means with their standard errors represented by vertical bars. Mean values were significantly different from those in the highest quartile: ${ }^{*} P<0.05$, ${ }^{* *} P<0.01$. (From Hannan et al. 2000; reproduced with permission). et al. (2001) reported that a high animal:plant protein intake was associated with increased bone loss from the hip and also with hip fractures in women aged $\geq 65$ years. $\mathrm{Ca}$ and protein intakes tracked together in that study, but adjustment for $\mathrm{Ca}$ intake did not alter the associations between the animal:plant protein intake and bone loss or hip fracture rates.

The reasons for the diversity of findings for the relationship between protein intake and bone are not entirely clear but a similar diversity has been noted in observational studies of other nutrients, including $\mathrm{Ca}$, and their associations with BMD, change in BMD and fracture incidence.

\section{Protein supplementation studies}

Several studies have examined the impact of dietary protein supplementation in elderly patients with recent hip fractures. In a randomised study of fifty-nine patients (Delmi et al. 1990) a dietary supplement containing $20 \mathrm{~g}$ protein/d and $500 \mathrm{mg} \mathrm{Ca} / \mathrm{d}$ for only 4 weeks improved the clinical course of these patients over the following 6 months. Notably the patients in the control group had a low mean $\mathrm{Ca}$ intake of $400 \mathrm{mg} / \mathrm{d}$ and a low mean protein intake of about $32 \mathrm{~g} / \mathrm{d}$. In a subsequent study in patients with acute hip fracture, supplementation with $20 \mathrm{~g}$ protein/d for 6 months increased serum IGF-1 levels (as indicated earlier) and reduced the rate of bone loss in the contralateral hip during the year after the fracture (Schürch et al. 1998). In this study both the protein-supplemented and control groups were given a large oral dose of vitamin $\mathrm{D}$ at the outset and $550 \mathrm{mg} \mathrm{Ca} / \mathrm{d}$ throughout the study. From this study it can be concluded that in elderly subjects with low usual intakes of dietary protein supplementation with $20 \mathrm{~g}$ protein/d has skeletal benefits.

\section{Potential interaction of calcium and protein with bone}

There are several reasons to believe that $\mathrm{Ca}$ intake may influence the net effect of protein on the skeleton. A higher $\mathrm{Ca}$ intake results in more absorbed $\mathrm{Ca}$, which may offset the urine losses. $\mathrm{Ca}$, by lowering the turnover rate, may reduce the adverse effect of mild acidosis on bone resorption.

Although not a consistent observation (Promislow et al. 2002), two studies suggest that $\mathrm{Ca}$ intake may influence the impact of dietary protein on the skeleton. In a large observational study, 39787 subjects, there was no clear association between either $\mathrm{Ca}$ intake or protein intake from non-dairy animal sources and the incidence of hip fracture (Meyer et al. 1997). However, subjects with the combination of low $\mathrm{Ca}$ intake $(<435 \mathrm{mg} / \mathrm{d}$; lowest quartile bound) and high non-dairy animal protein intake $(>20.6 \mathrm{~g} / \mathrm{d}$; highest quartile bound) were at approximately double the risk of hip fracture (relative risk 1.96 (CI $95 \%$ 1.09, 3.56)) compared with other subjects in the study (see Fig. 5).

Recently, the association between protein intake and changes in BMD was investigated in healthy men and women aged $\leq 65$ years who had participated in a 3-year randomised controlled trial. In the trial subjects took either $500 \mathrm{mg} \mathrm{Ca}$ as calcium citrate malate plus $17 \cdot 5 \mu \mathrm{g}$ vitamin $\mathrm{D} / \mathrm{d}$ or a double placebo. The mean total $\mathrm{Ca}$ intakes of the two groups were 1346 (SD 378) and 871 (SD 413) $\mathrm{mg} / \mathrm{d}$ and mean vitamin D 
intakes were 22.5 and $5 \mu \mathrm{g} / \mathrm{d}$ respectively. The supplemented group also consumed an additional $25 \mathrm{meq}$ alkali potential, from the citrate malate. The main results of the trial were that supplementation lowered the bone turnover rate by $10-15 \%$, reduced bone loss from the spine, hip and total body and lowered clinical fracture rates. It is likely that the $\mathrm{Ca}$, vitamin $\mathrm{D}$ and the citrate malate contributed to the supplement effect (Dawson-Hughes et al. 1997).

For the protein and bone analyses, 342 subjects were divided into tertiles of total protein as \% energy. Mean total

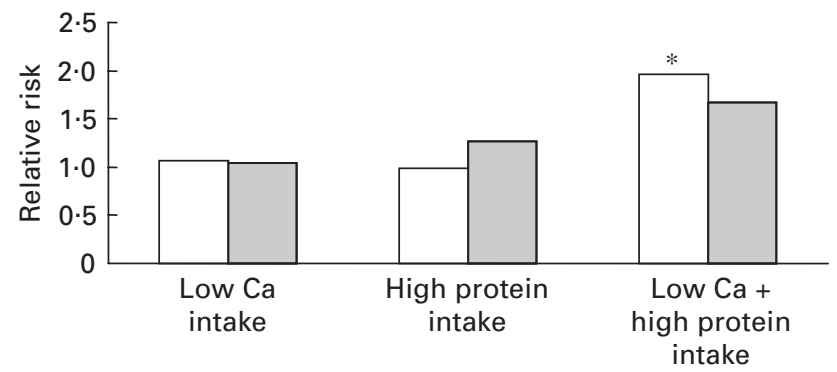

Fig. 5. Dietary calcium and protein intakes and hip fracture risk of subjects with low $\mathrm{Ca}$ intake $(<435 \mathrm{mg} / \mathrm{d})$, high protein intake $(>20.6 \mathrm{~g} / \mathrm{d})$ or a combination of low Ca intake and high protein intake. $(\square)$, Women; $(\square)$, men. Mean value was significantly different from those for the other groups: ${ }^{*} P<0 \cdot 05$. (From Meyer et al. 1997; reproduced with permission).
Table 1. Dietary and laboratory characteristics by tertile of protein intake (\% energy) for healthy men and women aged $\leq 65$ years who participated in a 3-year randomised control trial and received $500 \mathrm{~g}$ calcium citrate malate plus $17.5 \mu \mathrm{g}$ vitamin $\mathrm{D} / \mathrm{d}$ (supplement) or a double placebo

\begin{tabular}{lccc}
\hline Tertile. . . & \multicolumn{2}{c}{2} & 3 \\
\hline $\begin{array}{l}\text { Total protein intake (g/d) } \\
\quad \text { Placebo }\end{array}$ & 67.4 & 81.8 & 86.7 \\
$\quad$ Supplement & 71.7 & 79.3 & 88.6 \\
Ca (mg/d) & & & \\
$\quad$ Placebo & 755 & 918 & 940 \\
$\quad$ Supplement & 809 & 885 & 847 \\
K (mg/d) & & & \\
$\quad$ Placebo & 3190 & 3517 & 3369 \\
$\quad$ Supplement & 3324 & 3514 & 3316 \\
Serum PTH (pmol/l) & & & \\
$\quad$ Placebo & 4.4 & 4.9 & 4.9 \\
$\quad$ Supplement & 3.2 & 3.2 & 3.5 \\
24 h urinary Ca:Cr & & & \\
$\quad$ Placebo & 282 & 354 & 305 \\
$\quad$ Supplement & 421 & 421 & 474 \\
24h urinary Na:Cr & & & \\
$\quad$ Placebo & 13380 & 13781 & 13682 \\
$\quad$ Supplement & 13169 & 14887 & 15251 \\
24h urinary K:Cr & & & \\
$\quad$ Placebo & 3762 & 3775 & 4010 \\
$\quad$ Supplement & 3815 & 3956 & 3922 \\
\hline
\end{tabular}

PTH, parathyroid hormone; $\mathrm{Cr}$, creatinine.
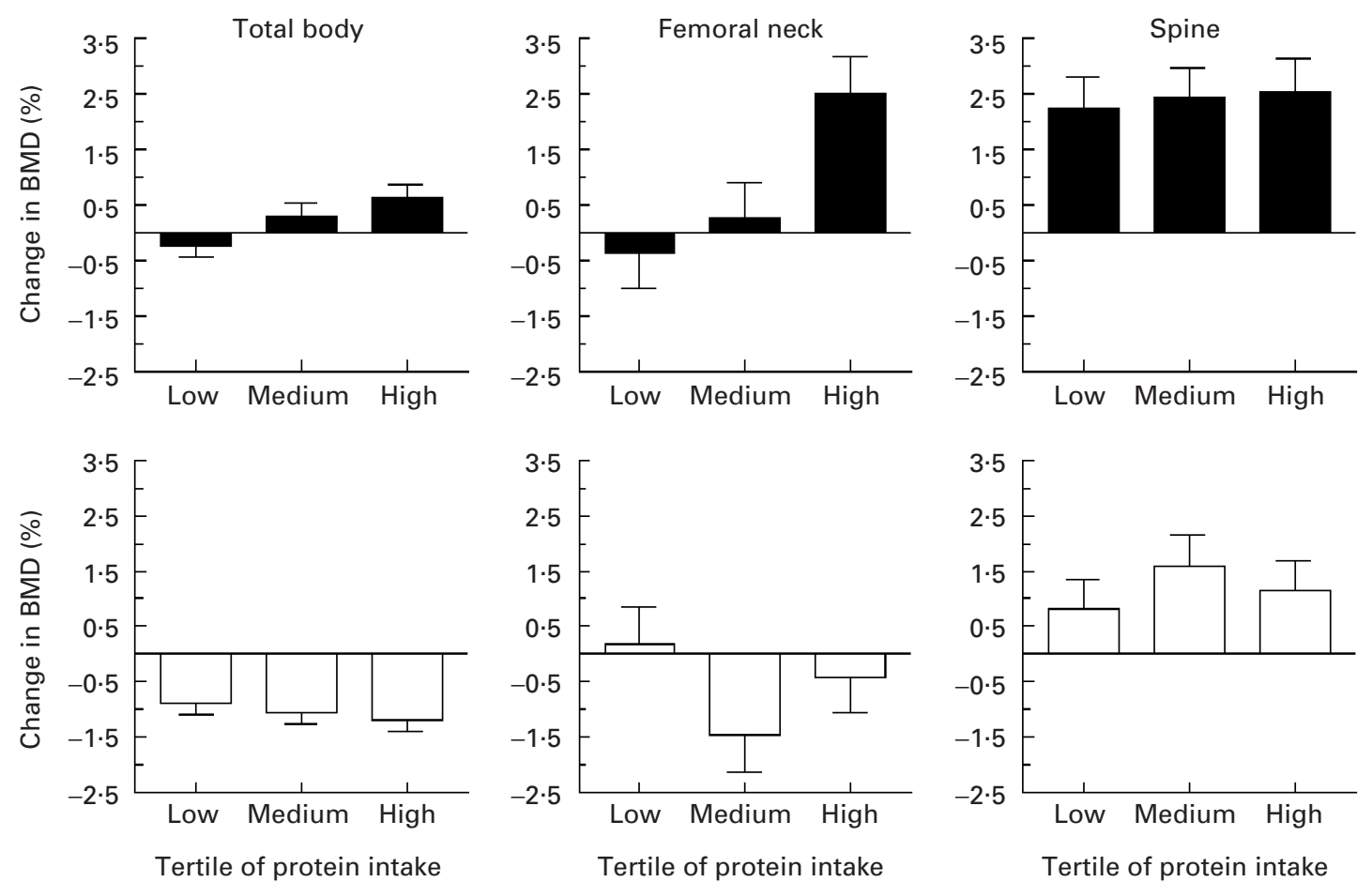

Fig. 6. The association between protein intake and rates of bone loss in 342 elderly men and women treated for 3 years with $500 \mathrm{mg} \mathrm{Ca}$ as citrate malate plus $17.5 \mu \mathrm{g}$ vitamin $\mathrm{D}(\square)$ and with placebo ( $\square$ ). BMD, bone mineral density. Values are means with their standard errors represented by vertical bars. For the total body there was a significant interaction of treatment group $\times$ protein tertile $(P=0.044)$. (From Dawson-Hughes \& Harris 2002; reproduced with permission). 
protein intakes of the three tertiles were 69,80 and $88 \mathrm{~g} / \mathrm{d}$. By analysis of covariance there was a significant interaction for treatment group $v$. protein $(P=0 \cdot 044)$, indicating that supplement status would influence any association between protein and change in bone density at the total body level. Several dietary and biochemical values for the protein tertiles are shown in Table $1 . \mathrm{Ca}$ and $\mathrm{K}$ intakes and serum parathyroid hormone levels did not differ significantly across the tertiles in either treatment group. Similarly, $24 \mathrm{~h}$ urinary $\mathrm{Ca}, \mathrm{Na}$ and $\mathrm{K}$, each corrected for creatinine excretion, did not differ across the tertiles. As reported earlier, the supplemented group had lower levels of parathyroid hormone and higher levels of urinary $\mathrm{Ca}$. Changes in BMD by tertile of total protein intake are shown for the supplemented and placebo groups in Fig. 6 (Dawson-Hughes \& Harris, 2002). Higher protein intake was associated with a favourable change in total body BMD in the supplemented group but not in the placebo group. Femoral neck BMD also increased with increasing protein intake in the supplemented group but not the placebo group, although the interaction at this site was not significant. Serum IGF-1 levels did not differ across the protein tertiles in either the supplemented or the placebo subjects. Serum osteocalcin and $24 \mathrm{~h}$ urinary $\mathrm{N}$-telopeptide levels were lower in the supplemented group than the placebo group, but did not differ across protein intake tertiles in either treatment group. Collectively these findings suggest that a higher $\mathrm{Ca}$ intake may reduce or offset the negative effect of protein on $\mathrm{Ca}$ retention and/or amplify the positive effect of IGF-1 or other factors on bone mass. Protein intervention studies are needed to examine more rigorously the impact of dietary protein on serum IGF-1, biochemical markers of bone turnover and other skeletal measures at different $\mathrm{Ca}$ intake levels.

In conclusion, the impact of dietary protein on the skeleton does not appear to be linear. A low intake is deleterious to bone health in the elderly and excessive intake is expected to be harmful. The threshold value remains to be defined. Dietary $\mathrm{Ca}$ intake and other factors may influence the impact of dietary protein on the skeleton.

\section{References}

Bushinsky DA, Parker WR, Alexander KM \& Krieger NS (2001) Metabolic, but not respiratory, acidosis increases bone PGE(2) levels and calcium release. American Journal of Physiology 281, F1058-F1066.

Cadogan J, Eastell R, Jones N \& Barker ME (1997) Milk intake and bone mineral acquisition in adolescent girls: randomised, controlled intervention trial. British Medical Journal 315, $1255-1260$.

Dawson-Hughes B \& Harris SS (2002) Calcium intake influences the association of protein intake with rates of bone loss in elderly men and women. American Journal of Clinical Nutrition $\mathbf{7 5}$, 773-779.

Dawson-Hughes B, Harris SS, Krall EA \& Dallal GE (1997) Effect of calcium and vitamin D supplementation on bone density in men and women 65 years of age or older. New England Journal of Medicine 337, 670-676.

Delmi M, Rapin CH, Bengoa JM, Delmas PD, Vasey H \& Bonjour JP (1990) Dietary supplementation in elderly patients with fractured neck of the femur. Lancet 335, 1013-1016.

Feskanich D, Willett WC, Stampfer MJ \& Colditz GA (1996) Protein consumption and bone fractures in women. American Journal of Epidemiology 143, 472-479.

Hannan MT, Tucker KL, Dawson-Hughes B, Cupples LA, Felson DT \& Kiel DP (2000) Effect of dietary protein on bone loss in elderly men and women: the Framingham Osteoporosis Study. Journal of Bone and Mineral Research 15, 2504-2512.

Heaney RP, McCarron DA, Dawson-Hughes B, Oparil S, Berga SL, Stern JS, Barr SI \& Rosen CJ (1999) Dietary changes favorably affect bone remodeling in older adults. Journal of the American Dietetic Association 99, 1228-1233.

Hegsted M \& Linkswiler HM (1981) Long-term effects of level of protein intake on calcium metabolism in young adult women. Journal of Nutrition 111, 244-251.

Higashi Y, Takenaka A, Takahashi S \& Noguchi T (1996) Effect of protein restriction on the messenger RNA contents of bone-matrix proteins, insulin-like growth factors and insulin-like growth factor binding proteins in femur of ovariectomized rats. British Journal of Nutrition 75, 811-823.

Kerstetter JE, Looker AC \& Insogna KL (2000) Low dietary protein and low bone density. Calcified Tissue International $\mathbf{6 6}$, 313.

Kerstetter JE, O’Brien KO \& Insogna KL (1998) Dietary protein affects intestinal calcium absorption. American Journal of Clinical Nutrition 68, 859-865.

Kraut JA, Mishler DR, Singer FR \& Goodman WG (1986) The effects of metabolic acidosis on bone formation and bone resorption in the rat. Kidney International 30, 694-700.

Meyer HE, Pedersen JI, Loken EB \& Tverdal A (1997) Dietary factors and the incidence of hip fracture in middle-aged Norwegians. A prospective study. American Journal of Epidemiology 145, 117-123.

Munger RG, Cerhan JR \& Chiu BC (1999) Prospective study of dietary protein intake and risk of hip fracture in postmenopausal women. American Journal of Clinical Nutrition 69, 147-152.

Oxlund H, Mosekilde L \& Ortoft G (1996) Reduced concentration of collagen reducible cross links in human trabecular bone with respect to age and osteoporosis. Bone 19, 479-484.

Promislow JHE, Godoman-Gruen D, Slymen DJ \& Barrett-Connor E (2002) Protein consumption and bone mineral density in the elderly. American Journal of Epidemiology 155, 636-644.

Schürch MA, Rizzoli R, Slosman D, Vadas L, Vergnaud P \& Bonjour JP (1998) Protein supplements increase serum insulinlike growth factor-I levels and attenuate proximal femur bone loss in patients with recent hip fracture. A randomized, double-blind, placebo-controlled trial. Annals of Internal Medicine 128, 801-809.

Sellmeyer DE, Stone KL, Sebastian A \& Cummings SR (2001) A high ratio of dietary animal to vegetable protein increases the rate of bone loss and the risk of fracture in postmenopausal women. Study of Osteoporotic Fractures Research Group. American Journal of Clinical Nutrition 73, 118-122.

Sutton RA, Wong NL \& Dirks JH (1979) Effects of metabolic acidosis and alkalosis on sodium and calcium transport in the dog kidney. Kidney International 15, 520-533. 